\title{
Teachers and Student Difficulties in Teaching ESP for Tourist Department
}

\author{
Katarina Yulianti Koban ${ }^{1}$, Maria Antonia Lema ${ }^{2}$ \\ English Department \\ Faculty of Social Sciences Education and Humanities, \\ Muhammadiyah Maumere Teachers Training Institute \\ Maumere, NTT \\ wawanlabira@gmail.com
}

\begin{abstract}
This study aimed at investigating the difficulties of teaching ESP For Tourism Department. The data where taken from through observation, interview and study documents. Data collected by observation, interview and documentation, then, the researcher will write down the results of interviews with the English teacher and students This research shows that Professional English teachers often find it difficult when they have to teach English for Specific Purpose (ESP) as they need to do extra works like doing need analysis and creating the specific syllabus before teaching to make sure that the teaching-learning process will go smoothly. Student teachers, who have less experience in teaching, are likely to face greater difficulties in teaching ESP.
\end{abstract}

Keywords - Student teachers, difficulties, ESP, tourism department.

\section{INTRODUCTION}

The study of English continues to occupy an important place in the educational curriculum. In Indonesia English is regarded as one of foreign language to be taught at elementary school as a local content, and at secondary schools as a compulsory subject. At the secondary school especially in vocational school level, the study of English sometimes moved away from trends in general English, it has always retained its emphasis on practical outcomes. The concept of English language teaching is designed to unify specific needs of the learners. The English teachers emphasize learner's needs of English in which the purposes are expressed in functional terms. In the other hand, the general English is based on a conception of the kind of reality that the student has to deal with in English. For example, a General English course for teenagers will probably be written around the language-based activities of a stereotypical teenager.

Consciously or unconsciously, therefore, all sensible course designers must begin by trying to assess students 'specific needs. ESP is simply a narrowing of this needs spectrum. The ESP process of specialization should not result in the complete separation of one part of the language from another. One cannot simply hack off pieces of a language or of skills and then expect them to exist independently of anything else. Every discipline refers to others and each draws on the same reservoir of language. A science student who comes to grips with the past simple passive through the description of laboratory procedures is unlikely to lock that tense into that context for the rest of their English speaking life Besturkmen (2010).

The approach of language teaching which aims to unify the need of particular learners is called English for Specific Purpose (ESP). Paltridge and Starfield (2013) stated that English for specific purposes (ESP) refers to the teaching and learning of English as a second or foreign language where the goal of the learners is to use English in a particular domain. As for a broader definition of ESP, Hutchinson and Waters (1987) theorize that ESP is an approach to language teaching in which all decisions as to content and method are based on the learner's reason for learning.

There are also some characteristic of ESP. Dudley-Evans and St. John (1998: 4-5) stated that one of them is ESP programs are designed to cater to the discipline- or vocation-specific needs of learners with a different level of language ability to communicate for work or study purposes in specific disciplines. The other characteristic is ESP are informed by a theoretical orientation (approach) along with instructional design (design and procedure) and the materials and methods are developed or adapted to provide learners with needs responsive instruction. 
The scope of ESP is extremely limited which allows the learners learn English language for very restricted purposes and it trains the learners to handle specific situations in extremely limited linguistic settings. This kind of ESP teaching restricts itself to "limited number of phrases and expressions and these learners remain unable to use English in any setting other than the one they have been trained for.

Stern $(1989,1992) \quad[7,11]$ distinguished four types of ESP teaching objectives: proficiency, know- ledge, affective, and transfer. Proficiency objectives concern mastery of skills such as reading, writing, listening, and speaking. Knowledge objectives concern the acquisition of linguistic and cultural information, where linguistic knowledge objectives include language analysis and awareness of the systematic aspects of language; cultural knowledge objectives include control of socio-cultural rules i.e. mastery of the norms of society, values, and orientations and the ability to recognize culturally significant facts, knowing what is acceptable and what is not. Affective objectives concern the development of positive feelings toward the subject of study; they include attitudes toward attaining second language competence, socio-cultural competence, and language learning. Transfer objectives concern the ability to generalize from what has been learnt in one situation to other situations.

There was some empirical investigation into the effectiveness of ESP teaching in Indonesia. Kurniasih (2013) investigated the learners' need in learning English for accounting. The research focus on the needs of the ESP for accounting and the students thought on the ESP materials. The result of their research showed that from the 35 learners, $37.1 \%$ stated that they are learning English because they aimed to be able to communicate in English better and the rest of students, $62.8 \%$, stated that they aimed to be able to communicate in English well in the subject area of accounting activities. For the learners' want, the writers deduced that $80 \%$ of the accounting learners stated that they want to improve their speaking ability and $20 \%$ stated that they want to improve their writing ability. In learning English the writers found that 15 of the learners get bored, 9 learners hardly understood English material, 8 learners enthusiastically learn English, and 3 learners could not understand the teacher explanation easily. Overall, the writers concluded that the accounting learners did not find any relevance between the English materials that they had to learn in the class and their need in learning English as accounting learners.

Since ESP teachers have many roles to play, they tend to face many difficulties in teaching. Kurniasih (2013) investigated that the students got bored during the class. Fălăuş (2016) stated that there are two difficulties in TESP. The first challenge he mentions is course design. Designing a course in ESP, according Fălăuş(2016) requires the teachers to do need analysis, to arrange the syllabus, and to decide the appropriate methodology to be used in teaching which require teacher to adjust with the characteristics of the learners. Meanwhile, the second challenge is the five roles mentioned in the previous section. Different from Fălăuş (2016), Hoa and Mai (2016) provide a more extensive explanation about the difficulties in TESP. They classify the challenges into three major categories, challenges related to students, challenges related to teachers, and difficulties related to the environment or others.

The study above shown that English teachers vocational school English teachers has been dealing with a lot of problems, such as their poor English proficiency, their passive performance, and their low interest and motivation in learning. Worst of all, most of students haven't even had autonomous learning ability and rely too much on teachers, thus it is teachers who do most of the work, explaining everything and talking for over $90 \%$ of the class time, and eager to get out of such a difficult situation.

Meanwhile, it is supposed that ESP should be taught by teachers who are experts in a specific major with high English level, which could guarantee that an ESP instructor helps students with both technical content of a course as well as language issues. Moreover, to be a good ESP instructor, a language teacher should have a natural desire to keep up the latest findings in science and technology.

In the other hand, the National Curriculum provides the teacher with a general course framework but does not define the specific topics, skills, or approaches to be used in an ESP course. The list of recommended materials is too short and does not suit the needs of the vocational school students. There are some textbooks and teaching materials for teaching but cannot completely satisfy the needs of a specific them and therefore the teacher's role is to mediate the materials to the students.

So how to motivate students' interests and autonomy in ESP learning and how to find an effective way to expose ESP teachers to more authentic professional knowledge of a certain major has become an urgent issue. At present, the writer is inspired to conduct a research concerning with the difficulties of ESP teaching at vocational school of tourism department.

\section{METHOD}

Base on the background above, the writer conducted a research which is focused on analysis of learners' needs in learning English for specific purposes using the same research design in a bigger scale of samples in different field. This research was took place in suburb area in Maumere, Flores island East Nusa Tenggara at a vocational school of English department. The data were collected through questionnaire and interview. The researcher used three steps to analyze the data. Firstly, the researcher arranges the mass data in good order, so that data 
analysis can be done easily. Secondly, the researcher will write down the results of interviews with the English teacher and students about the teacher's strategy in implementing English for specific purposes in class. Then the data is synthesized from the teacher or student and make technical indexes and other related data. Thirdly, the researchers describe the results of student and teacher interviews. The final step is, the researcher gives meaning and interprets the data. When all data has been analyzed, researchers begin to describe the findings and all data will be presented descriptively.

\section{FINDING AND DISCUSSION}

Having the data collected and analyzed, the study found an interesting fact. The student teachers participated in the study, expressed similar difficulties in teaching ESP for tourism department. They are teaching facilities, time management, different levels of English proficiency, and low selfefficacy.

Referring to the classification of teaching ESP difficulties proposed by Hoa and Mai (2018), the findings of the study fall into two categories, difficulties related to students which include time management, different level of proficiency and selfefficacy and difficulties related the environment/others i.e. teaching facilities. The study also found that the student teachers did not write about the difficulties related to themselves as the teachers.

\section{Teaching Facilities}

The first difficulty faced by the student teachers was the lack of teaching facilities. Different from schools, tourist objects are not prepared for education. Though there are many different tourist objects across the region that can be used for teaching practicum, they are actually meant for business purposes. Thus, all of them occupied private tourist objects. This condition made the teachinglearning process not effective.

\section{Time Management}

The next difficulty faced by the student teachers is that the hotel staffs do not have good time management. They often come late and skip the classes. This had made the student teachers feel very confuse. While the student teachers had prepared the lesson plan for one meeting lasted two hours, they rarely can finish the lesson.

\section{Different Levels of Proficiency}

English courses usually require their students to take a placement test because it is easier for teachers if they can teach students with similar levels of proficiency in a class. However, student teachers were asked to teach all of the staff with no regard to their level of English proficiency.
Self-Efficacy

Another difficulty mentioned by all of the student teachers in teaching ESP is that many of the learners, have low self-efficacy in learning English. Bandura, (1994) defines self-efficacy as"people's beliefs about their capabilities to produce designated levels of performance that exercise influence over events that affect their lives". This means the learners do not have enough confidence in learning English.

\section{REFERENCES}

[1] Bandura, A. (1994). Self Efficacy. (V. S. Ramachaudran, Ed.) Bandura, A. (1994).Selfefficacy. In $V$. Encyclopedia of human behavior (Vol. 4, pp. 71-81). NewYork: Academic Press., 4, 71-81.

[2] Basturkmen, H. (2017). ESP teacher education needs. Language Teaching, 1-13.

[3] Dudley-Evans, A., \& St. John, A. (1998). Developments in ESP: A multidisciplinaryapproach. Chambrigde: Cambridge University Press.

[4] Fălăuş, A. (2016). The current difficulties of teaching ESP.

[5] Hoa, N. T., \& Mai, P. T. (2016). Difficulties in Teaching English for Specific Purposes: Empirical Study at Vietnam Universities. Higher Education Studies, Vol 6.

[6] Hutchison, T., \& Waters, A. (1987). English for Specific Purposes: a learner-centredapproach. England: Chambrigde University Press.

[7] Hui, G. (2017). The learning needs analysis of English for Specific Purposes (ESP) in college. US-China Foreign Language, 15(1), 1-6.

[8] Pham, H. A., \& Ta, B. T. (2016). Developing a theoretical framework for ESP teacher training in Vietnam. The Asian ESP Journal, 12(1), 6684.

[9] Ramirez, C. G. (2015). English for Specific Purposes: Brief history and definitions. Revista de Lenguas Modernas, 23, 379-386. 